Review

\title{
Benefits of Combined Liver Transplant: Protection or Tolerance?
}

Salim Hamdani ${ }^{1, *}$, Daniel Azoulay ${ }^{1,2}$

1. Department of Hepatobiliary and Pancreatic Surgery and Liver Transplantation, Paul Brousse Hospital, Villejuif, France; E-Mails: salimhamdani.a.m@hotmail.fr; daniel.azoulay@aphp.fr

2. Department of Hepatobiliary and Pancreatic Surgery and Transplantation, Sheba Medical Center, Faculty of Medicine Tel Aviv University, Israel

* Correspondence: Salim Hamdani; E-Mail: salimhamdani.a.m@hotmail.fr

Academic Editor: Jean Kwun

Special Issue: Multiple Aspects of Transplant Tolerance - Mechanisms, Strategies, and Barriers

OBM Transplantation

2019, volume 3 , issue 3

doi:10.21926/obm.transplant.1903084
Received: April 18, 2019

Accepted: August 26, 2019

Published: September 04, 2019

\begin{abstract}
The privileged liver, due to its immunological status, is referred to as a tolerogenic organ. However, this alone does not explain the introduction of tolerance after single or combined liver transplantation (kidney, heart, pancreas, and intestine); other factors, such as recipient's age, donor's hepatic volume, iron metabolism, biomarkers, or imprint of cytomegalovirus infection, appear to be involved in the identification of patients who are likely to be tolerant to their graft. All the afore-stated factors appear to favor graft tolerance. The use of non-specific immunosuppressive drugs during organ transplantation has reduced the incidence of acute rejection significantly, although it does not protect the patient from the deleterious effects of chronic immunosuppression. Therefore, different approaches, such as stem cells infusion, Treg therapy, and immunosuppression conversion, have been utilized in order to reduce or discontinue the use of immunosuppressive therapy. The present review of the literature examined the mechanisms of tolerance occurring after hepatic transplantation (alone or combined), as well as the currently available means for the early identification of patients who might be the candidates for tolerance.
\end{abstract}

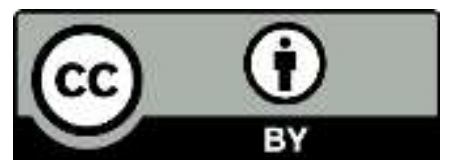

(C) 2019 by the author. This is an open access article distributed under the conditions of the Creative Commons by Attribution License, which permits unrestricted use, distribution, and reproduction in any medium or format, provided the original work is correctly cited. 


\section{Keywords}

Liver transplantation; combined transplant; tolerance

\section{Introduction}

The liver is a tolerogenic organ, owing to its microanatomy, its cellular composition, and the cytokine environment. It exhibits an easier acceptance of the hepatic graft when compared to other solid organ transplants. Hepatic transplantation has significantly improved the survival of patients suffering from end-stage liver disease. However, the transplantation is doomed to failure in the absence of immunosuppression (IS). The 5-year survival rate among the transplant patients has increased from $20 \%$ to greater than $60 \%$ in the 1980 s and greater than $70 \%$ in recent years. Non-specific immunosuppressive agents, such as calcineurin inhibitors (CNIs) and mTOR inhibitors, are considered synonymous with control of rejection and side effects. In long term, the patients exposed to this treatment are at the risk of dysmetabolic syndromes, cardiovascular complications, neurotoxicity, de novo cancers, and renal complications [1-4]. One of the therapeutic approaches in this regard has been to avoid CNIs (dose reduction, conversion, or total cessation) and minimize the corticosteroid drugs while maintaining function. It is currently accepted that the conversion of CNIs to mTOR inhibitors in pre-selected patients serves as a good alternative to minimizing the immunosuppressive treatments. The customization of treatment in the patients with criteria suggesting a state of tolerance is another strategy that relies on biomarkers, although it is also dependent on the immunomodulatory effects of cell therapy. Operational tolerance is a state when the recipients are immunocompetent and tolerate their grafts without the requirement of any IS. Operational tolerance represents $20 \%$ of all the liver transplants [5]. Since the 1950s, when the proof of concept was established [6, 7], various studies have demonstrated that several mechanisms are involved in the induction of tolerance. Acting alone or in concert, these mechanisms converge on a single goal of restoring homeostasis. The first case of operational tolerance was reported sixty years ago, the case report from Joseph Murray, in which he presented a case of kidney graft without using immunosuppressive treatment, and the graft was prepared from his homozygous twin [8]. A few years later, it was the turn of liver transplantation, with the concept of microchimerism in tolerance [9]. Since those times, the cases of operational tolerance have been reported more frequently in the recipients of liver transplant compared to any other organ transplant. Since liver is a "tolerogenic organ", it was assumed that it exerted a protective influence on the second graft in the combined grafts. However, the study by Rana demonstrated that recipients receiving two lungs or two kidneys were less subjected to rejection and exhibited improved survival compared to the recipient receiving only one graft [10]. In liver-kidney/liver-heart transplantation, rejection rate was observed to be reduced to almost half compared to the isolated grafts.

The present review of the literature discusses the current state-of-the-art on clinical tolerance in combined liver transplantation, and the related survival rate. 


\section{Mechanisms}

At the micro-environmental scale, the immunological events participating in this state of tolerance remain unclear. However, each piece of the puzzle appears to be important. Hepatic tolerance is a part of the benefits of transplantation [11], favoring the persistence of hepatotropic viruses. One of the evoked tracks, especially in renal transplantation, is the involvement of passenger leukocytes in the initiation of rejection. Indeed, the rejection of the transplants due to transient depleted passenger leukocytes may be reversible through the adoptive transfer of donor antigen-presenting cells [12]. In the liver, these donor-derived cells are mainly represented by activated T-cells, Natural-Killer cells, as well as the resting T- and B-lymphocytes. In order to elucidate the functional relevance of microchimerism in allograft tolerance, a study was conducted on a cardiac allograft model in cyclosporine-treated rats. The depletion of donorderived leukocytes in the recipient was achieved at the time of grafting (Day 0 ) and at a time point far from it (Day 18). The ones for whom the depletion was performed at Day 18 did not exhibit any signs of rejection and exhibited survival similar to a syngeneic control group. On the contrary, those for whom depletion was performed at Day 0 exhibited signs of severe chronic rejection [13]. Additionally, the absence of viable transient leukocytes in the liver at the time of transplantation resulted in the rejection of the graft. Surprisingly, spontaneously tolerant transplant model was observed to exhibit correlation between early passenger leukocyte migration and a transient increase in the expressions of IL2 and IFNY. This phenomenon is paradoxically less important during an acute rejection [14]. Moreover, low concentrations of IL2 and IFNY appear to be insufficient for inducing rejection, although it may promote the state of tolerance through the process of negligent death of the allo-reactive T cells [15]. Although the procedure was considered safe, the in vitro treatment through kidney perfusion of an antibody solution (monoclonal antiCD45 antibodies specific for passenger leukocytes) into the human recipients prior to transplantation revealed no evidence of reduced incidence of acute rejection [16]. Another hypothesis suggested the persistence of a small percentage of graft-derived leukocytes in several recipient tissues (microchimerism) [17, 18]. However, it was reported that microchimerism alone was not automatically correlated with long-term allograft survival [19]. As with passenger leukocytes, the donor hematopoietic stem cells present in the liver also contributed to the persistent microchimerism $[9,17,20]$ because of an abundance of these long-living cells in the liver transplant donors. The resident cells of liver, which are closely related to the intestinal microbiome [21, 22], are represented by parenchymal cells (hepatocytes) and non-parenchymal cells (Kupffer cells, stellate cells, hepatic sinusoidal endothelial cells, and dendritic cells). These cells have active participation in the tolerogenic effects. One of the properties of hepatocytes is the presentation of the antigen to naive $\mathrm{CD} 8^{+} \mathrm{T}$ cells. This successful process results in the deletion of $\mathrm{CD}^{+}$since it is insufficiently activated for the induction of permanent cytotoxic function [23, 24]. Non-parenchymal liver cells have been reported to be influenced by pattern recognition receptors (PRRs), such as the NOD-like receptors and Toll Like Receptors (TLRs) [22, 25], which play important roles in the innate immunity. The phenotype of tolerogenic cells derived from the mononuclear phagocyte systems such as Kupffer cells and the immature dendritic cells is a moderate expression of MHC (major histocompatibility complex) class II on their surface [26], low CD80/CD86 co-stimulation [27], and the expression of the immunosuppressive factor PDL-1 [28]. In addition, the medium rich in IL-10 and TGF- $\beta$ production $[29,30]$ may lead to the tolerance via 
differentiation of the naive T cells into regulatory phenotypes, as well as through apoptosis of the $\mathrm{CD}^{+}$and $\mathrm{CD}^{+}$effector T cells, thereby achieving the induction of donor-specific hypo-reactivity. The induction of systemic tolerance by the antigen-presenting cells (APC) of liver has been attributed to both peripheral suppression and the induction of antigen-specific Treg cells. Recent data have demonstrated that hepatic stellate cells also induce the expansion of regulatory $T$ cells (Treg) [31]. A recent study demonstrated the involvement of novel machinery in liver transplantation tolerance, which comprises stellate and endothelial cells, through a mechanism referred to as mesenchyme-mediated immune control (IMMC). The action of IMMC is induced through the production of IFNy by effector T cells, which leads to the expression of PD-L1 in the stellate cells, and by endothelial cells, which leads to apoptosis of the effector T cells. In addition, both stellate and endothelial cells produce soluble factors, such as retinoic acid and iC3b, in order to promote myeloid-derived suppressor cells (MDSCs) and Tregs [32]. This highlights the fact that the survival of Tregs appears to be under continuous influence of the donor antigen [33]. The infusion of donor-specific Treg-enriched $\mathrm{T}$ cells from the liver to the recipient after liver transplantation exhibited the presence of donor-derived Tregs in the recipient's circulation one week after the transplantation. The author suggested that a few of the donor's Tregs come off the graft during the infusion and migrate into the general circulation. In addition, the in vitro tests confirmed their suppressive abilities [34]. An increase in $\mathrm{CD} 4^{+} \mathrm{CD} 25^{+} \mathrm{FoxP} 3^{+} \mathrm{CTLA} 4^{+}$Treg has also been observed in the mouse model of tolerogenic liver transplantation, whereas the depletion of this population by the action of anti-CD25 antibody results in acute rejection, which indicates an important role of Tregs in maintaining tolerance during allogeneic liver transplantation [35]. However, the role of Treg in liver transplantation remains controversial, because according to the study conducted by Joffre et al., Treg with direct allo-specificity alone does not provide protection against chronic rejection [36], which supports the idea that Tregs require direct and indirect allorecognition in order to control allograft rejection [37]. Another track reported a close relationship between the graft surface and antigenic charge. Prolonged exposure to a high antigen load appeared to contribute to lymphocytic senescence through a dilution phenomenon as well as to a state of operational tolerance [38, 39]. In case of combined grafts (liver-kidney and heart-kidney), a reduction in the renal graft rejection rate was observed compared to kidney transplant (KT) alone [40], and the hypothesis suggested that there was an obvious relationship between the grafted surface and antigenic charge. Both experimental and clinical studies have demonstrated the role of soluble $\mathrm{MHC}$ in tolerance, and the different mechanisms explaining the manner in which the MHC class I presents have been suggested, such as (i) a direct interaction between MHC class I and the CD8 allo-reactive lymphocyte in the absence of co-stimulation signaling, which leads to their apoptosis, (ii) presentation of the antigen via tolerogenic presenting cells, which allows differentiation from $T_{h 1}$ response to $T_{h 2}$ regulatory phenotype, and finally (iii) the ability of the soluble MHC molecules to neutralize the lymphocytotoxic allo-antibodies. Pathogen recognition involves both classical and non-classical $\mathrm{MHC}$ class I soluble molecules. In case of the non-classical MHC class I soluble molecules, it has been observed that HLA-G (Human Leucocyte Antigen) molecules possess multiple regulatory and tolerogenic immune properties. Indeed, the recipients of a combined liver-kidney transplant exhibit a higher concentration of serum HLA-G, compared to those with kidney grafts alone, which has been associated with lower allograft rejection frequencies [41]. In liver transplants, the patients with operational tolerability exhibit strong HLA-G expression on the surface of circulating monocytic dendritic cells which also 
promotes the Foxp3 gene expression [42]. Another interesting fact involves iron homeostasis. Bohne et al. [39] observed the overexpression of the gene encoding hepcidin in the patients with operational tolerance, as well as an increase in the serum levels of ferritin and hepcidin. The author concluded that iron metabolism has a role to play in the intrahepatic allogeneic response (Figure 1).

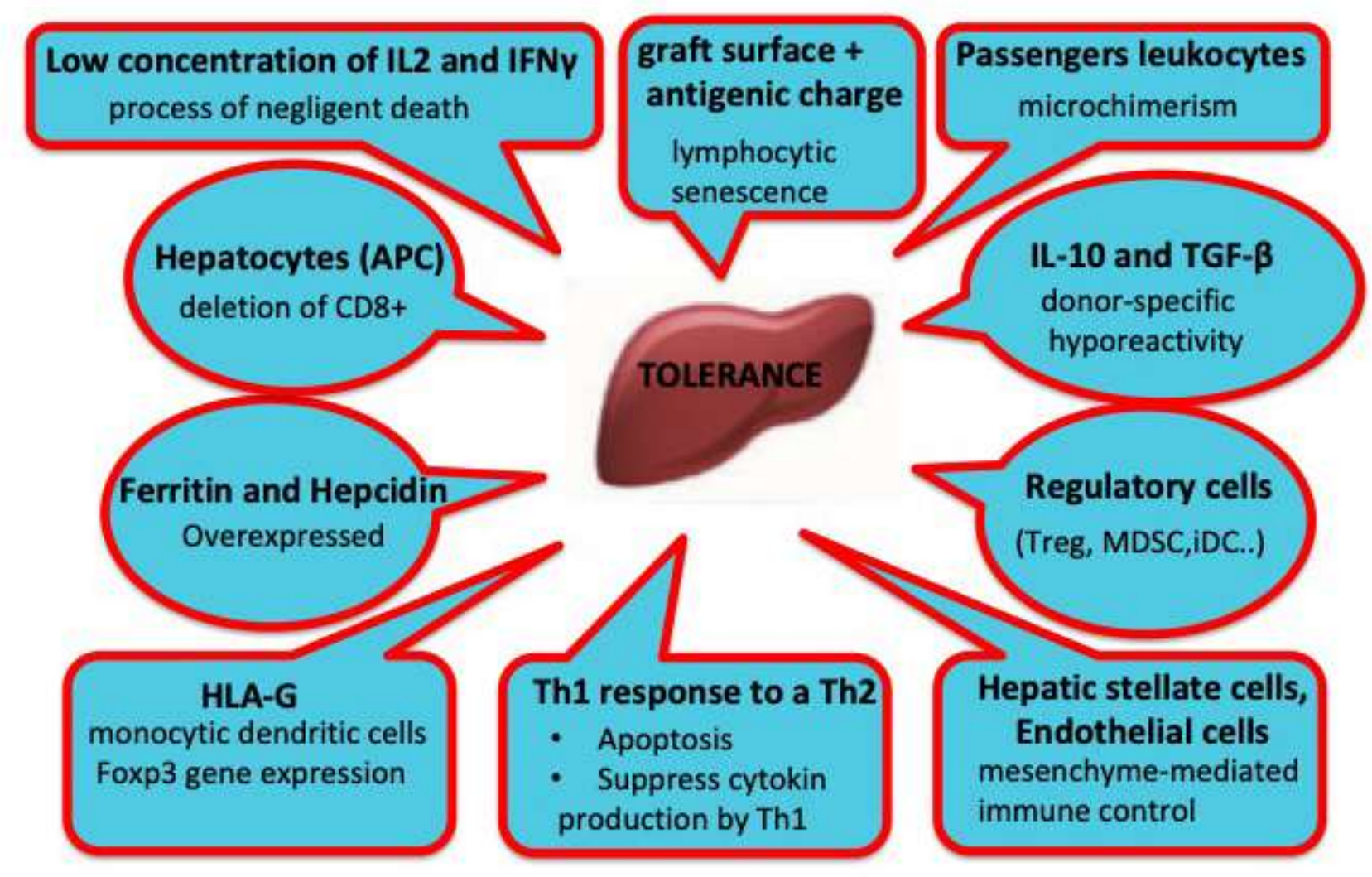

Figure 1 Mechanisms contributing to the tolerance in hepatic transplantation.

\section{Biomarkers}

Whatever the approach, classical techniques have their limits. The development of the "omic" methods of analysis (genomics, transcriptomics, proteomics, and metabolomics) combined with currently available clinical and biological data, allows the recognition of patients for whom immunosuppressive therapy may be terminated. Biomarkers, which generally have a role of prediction, have a role of prevention as well. The molecular signature of rejection or tolerance may vary between organs within the same individual. Indeed, in liver transplantation, the

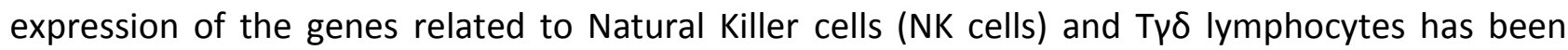
associated with tolerance; whereas, in renal transplantation, approximately $70 \%$ of the identified genes have been associated with B-lymphocytes. Two major consortia enabled the discovery and validation of certain biomarkers: the ITN (Immune Tolerance Network) in United State and the IOT (Indice Of Tolerance) in Europe. However, it was observed in a previous study that simple clinical criteria such as the age of the recipient and the timing of weaning after the transplantation could predict a state of tolerance in up to $40 \%$ of the transplant patients; this study (elective weaning 
protocol) demonstrated that the patients who were 50 years of age could start giving up their IS in a shorter period of time in comparison to those who were over 60 years of age [43]. Moreover, the Hepatitis C Virus (HCV) negative and non-autoimmune patients were more likely to shed the IS treatment. Immunophenotypic studies have mainly identified an increase in the frequency of Tregs and a predominance of the $T \gamma \delta V \delta 1^{+}$subpopulation of lymphocytes [44, 45]. However, alteration in the $T \gamma \delta \vee \delta$ lymphocytes has been observed during viral infections, in which there is an increase in the $V \delta 1 / V \delta 2$ ratio. This finding was obtained in a prospective, non-randomized, phase II, uncontrolled trial in which stable adult liver transplant $\mathrm{HCV}^{+}$patients underwent IS withdrawal. Contrary to the findings of a previous study concerning the barrier represented by inflammation in a state of tolerance [28], Bohne et al. described for the first time, the weaning of IS in HCV-positive patients despite a pronounced systemic expression of the pro-inflammatory gene; the author suggested that the intrahepatic expression of ISG (Interferon Stimulated Gene) could be an indicator of operational tolerance [38]. A similar phenomenon was observed in cytomegalovirus (CMV) infections, in which a primary infection allowed for the long-term expansion of the circulating $V \delta 1^{+} \gamma \delta T$ cells associated with the hyporeactivity of the donor-specific $\mathrm{CD}^{+} \mathrm{T}$ cells in the tolerant patients after a liver transplant [46]. Among the resident liver tolerogenic cells, plasmacytoid dendritic cells specialized in the production of type I interferons (IFN) were increased in number in stable adult and pediatric liver transplant recipients with arrest and withdrawal from IS [47]. Predicting rejection is another goal of biomarkers; therefore, an increase in IFNY and IL2 in stable patients grafted with the IS withdrawal liver, or before transplantation, represents a risk of rejection [48]. In renal transplantation, anti-HLA-specific donor antibodies (DSA) were reported to exert a negative impact on graft survival [49, 50], although their correlation in liver transplantation is not completely understood so far. In a study, high mean fluorescence intensity (MFI) of DSA was observed in $92 \%$ of the patients in chronic rejection in contrast to $61 \%$ of the non-rejection patients, after liver transplantation [51]. The same study demonstrated that the patients in chronic rejection exhibited a combination of 3 subtypes of immunoglobulin $(\operatorname{Ig}) \mathrm{G}(1,2,3)$, as opposed to the predominance of $\lg \mathrm{G} 3$ in the patients with graft loss [52]. There has been a loss of interest in the C4d labeling since chronic negativity suggesting the lack of complement activation in this situation has been observed. A European multicenter study-planned to determine the predictive biomarkers and pathogenesis of operational tolerance-identified two genes (HAMP and TFRC) coding for hepcidin (a peptide, secreted mainly by the hepatocytes and regulates plasma concentration of iron) and responsible for the increase in the plasma concentration of ferritin. Bohne et al. [39] also suggested a protective impact of iron metabolism on the cytotoxic effects of allo-immune response as well as the prognostic role of biomarkers in the identification of operatively tolerant recipients prior to IS arrest (Table 1). 
Table 1 Non-exhaustive list of biomarkers and clinical features found in the patients tolerant to liver transplantation: LT: Liver transplantation, IFN: Interferon, HVC: Hepatitis C virus, IS: Immunosuppression, CMV: Cytomegalovirus, HAMP: Hepcidin antimicrobial protein, TRFC: Transferrin receptor, Gr-Tol: Tolerant patients, Gr-Non-Tol: Non-Tolerant patients, Gr-Vol: Volunteers, Gr-IS: Patients on IS, Gr-A: Patients off immunosuppression, Gr-B: Patients undergoing prospective weaning, Gr-C: Patients on maintenance immunosuppression, Gr-D: Normal control, Gr-AR: Patients with acute allograft rejection, Gr-SF: Patients with stable allograft liver function, pDC1: Precursors of monocytoid DC, pDC2: Precursors of plasmacytoid DC.

\begin{tabular}{|c|c|c|c|c|c|c|c|c|}
\hline & Study & Cohort (N) & Source & Follow up & Indicator & Tolerance & Comment & Reference \\
\hline Age & $\begin{array}{l}\text { Prospective } \\
\text { Multicenter } \\
\text { clinical trial }\end{array}$ & $41 / 98$ & $\left\{\begin{array}{l}56 \text { y } 11 \\
(\text { Means } \pm S D)\end{array}\right.$ & $>3$ years & $>50$ years & $\uparrow$ & $\begin{array}{l}\text { Caucasian } \\
\text { men }\end{array}$ & [43] \\
\hline Weaning & $\begin{array}{l}\text { Prospective } \\
\text { Multicenter } \\
\text { clinical trial }\end{array}$ & $41 / 98$ & $\begin{array}{l}\text { Clinical } \\
\text { Parameters, } \\
\text { blood, biopsy }\end{array}$ & $>3$ years & $\begin{array}{l}\text { Male gender, } \\
\text { older recipient, } \\
\text { absence of } \mathrm{CNI}\end{array}$ & $\uparrow$ & $\begin{array}{l}\text { Time from } \\
\text { transplant } \\
\text { to } \\
\text { minimizatio } \\
\text { n start: } 130 \\
\text { months }\end{array}$ & [43] \\
\hline Tregs & $\begin{array}{l}\text { Pediatric Living } \\
\text { Donor Liver } \\
\text { Transplantatio } \\
\text { n (Elective } \\
\text { protocol) }\end{array}$ & $\begin{array}{l}\text { Gr-Tol: } 12 \\
\text { Gr-Vol: } 24 \\
\text { Gr-IS: } 19\end{array}$ & Blood & $>1$ year & $\mathrm{CD} 4^{+} \mathrm{CD} 25^{+}$cells & $\uparrow$ & $\begin{array}{l}\text { Gr-Tol vs Gr- } \\
\text { IS } \\
\text { ( } p<0.01) \\
\text { Gr-Tol vs Gr- } \\
\text { Vol }(p<0.01)\end{array}$ & [44] \\
\hline $\begin{array}{l}\text { Ty } \delta \text { V } \delta 1+ \\
\text { lymphocyte }\end{array}$ & $\begin{array}{l}\text { Adult liver } \\
\text { transplantation }\end{array}$ & $\begin{array}{l}\text { Gr-SF: } 37 \\
\text { Gr-AR: } 26\end{array}$ & Blood & 6 months & $\begin{array}{l}\text { The numbers of } \\
\text { IL-10-producing }\end{array}$ & $\uparrow$ & $\begin{array}{l}\text { Maintain } \\
\text { stable graft } \\
\text { liver }\end{array}$ & [45] \\
\hline
\end{tabular}




\begin{tabular}{|c|c|c|c|c|c|c|c|c|}
\hline & & & & & $\begin{array}{l}\text { V } \delta 1^{+} \text {cells were } \\
\text { higher in Gr-SF } \\
\text { patients than in } \\
\text { Gr-AR patients. }\end{array}$ & & function & \\
\hline $\begin{array}{l}\text { ISG } \\
\text { expression }\end{array}$ & $\begin{array}{l}\text { Prospective } \\
\text { study }\end{array}$ & $\begin{array}{l}\text { Gr-Tol: } 17 \\
\text { Gr-Non-Tol: } 15\end{array}$ & Intrahepatic & 12 months & $\begin{array}{l}\text { IFN-stimulated } \\
\text { gene (ISG) } \\
\text { transcript levels } \\
\text { were similar } \\
\text { before and } 12 \\
\text { months after } \\
\text { complete IS } \\
\text { withdrawal }\end{array}$ & $\uparrow$ & $\begin{array}{l}\text { High } \\
\text { intrahepatic } \\
\text { IFN-I } \\
\text { signaling } \\
\text { induced by } \\
\text { HCV } \\
\text { infection }\end{array}$ & [38] \\
\hline $\begin{array}{l}\text { Plasmacytoi } \\
\text { d dendritic } \\
\text { cells }\end{array}$ & $\begin{array}{l}\text { Prospective } \\
\text { study }\end{array}$ & $\begin{array}{l}\text { Gr-A: } 6 \\
\text { Gr-B: } 23 \\
\text { Gr-C: } 11 \\
\text { Gr-D: } 13\end{array}$ & Blood & $\begin{array}{l}1 \text { month - } \\
9 \text { years } \\
\text { (time } \\
\text { weaning) }\end{array}$ & $\begin{array}{l}\text { pDC2:pDC1 } \\
\text { ratio was } \\
\text { significantly } \\
\text { higher in } \\
\text { patients Gr-A } \\
\text { and B compared } \\
\text { with patients on } \\
\text { Gr-C. }\end{array}$ & $\uparrow$ & $\begin{array}{l}\text { Withdrawal } \\
\text { from IS }\end{array}$ & {$[47]$} \\
\hline
\end{tabular}


4. Tolerance in Combined Hepatic Transplantation (Figure 2).

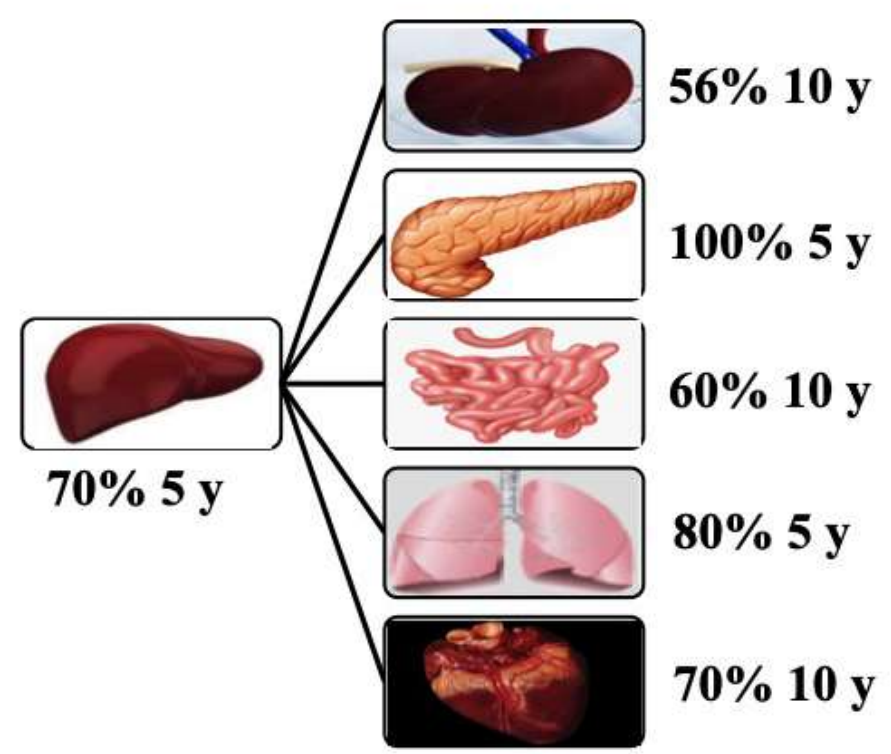

Figure 2 Survival rate in combined liver transplantation and liver transplant alone. Y: years.

\subsection{Liver-Kidney Transplant}

The indication leading to a combined kidney-liver transplantation was established as a treatment modality for the patients suffering from end-stage liver disease (MELD), which was a scoring system for liver transplantation, with highly elevated serum creatinine levels (risk factor) [53]. In a recent study, combined kidney-liver transplant patients with acute renal rejection exhibited a post-transplantation reduction in renal function compared to those without renal rejection [54]. The survival rate at one year for the patients and grafts currently exceeds $80 \%$, although with a decline in the survival rate at ten years (56\%-64\% for kidney-liver), which has prompted the researchers to focus their attention on improving the survival beyond one year. Although tolerance may change after the transplantation, the risk of minimizing IS is associated with decreased graft survival. Immunosuppression protocols vary between the transplantation centers, usually according to the CNIs used, such as tacrolimus. This immunosuppressive strategy tends to be closer to the adapted protocol in liver transplantation. Despite the short-term benefit of using CNIs in reducing the acute rejection episodes, CNIs are nephrotoxic in the long term, leading to the poor long-term survival of the transplant [55]. Besides the fact that the simultaneous graft has a lower rejection rate in comparison to the liver or kidney transplant alone, it was observed that the patients transplanted with either liver or kidney, and not the ones transplanted with both simultaneously, did not present any differences even after having been selected on the basis of their HLA compatibilities [10]. HCV-infected recipients with double liverkidney transplant and receiving no anti-viral treatment exhibited poor survival at three years as well as at five years [56]. Although the preliminary results demonstrated a novel approach to the treatment of HCV-infected patients, direct-acting anti-virals appeared to eradicate the hepatitis $\mathrm{C}$ virus with a sustained virological response up to $94 \%$, in addition to exhibiting far fewer side effects (reproached to interferons and ribavirin) [57]. A retrospective study conducted by an 
American research team revealed that approximately $20 \%$ of the combined liver-kidney transplantations resulted in renal rejection (6.4\% acute rejections and $11.4 \%$ borderline rejections (biopsies)), while $11.4 \%$ resulted in acute hepatic rejection [54]. In comparison to the renal transplantation alone, the effects of T-cell mediated rejection and anti-HLA antibody were relatively lower after simultaneous kidney transplantation [58]. Recently, a clinical study revealed the unique phenotypic and functional characteristics of the recipients of a dual simultaneous liverkidney transplant (SLKT) associated with a donor-specific hypo-allo-allergenic response. The SLKT patients had, from a phenotypic perspective, a central memory type profile, while the patients with renal transplant alone exhibited a regulatory type profile [59]. The gene expression profiles (mRNA and miRNA) in SLKT in comparison to the profiles of the liver and kidney transplant patients with stable transplant function clearly suggested that the SLKT patients had a profile closer to the liver transplant patients rather than the kidney transplant patients, associated with limited influence of IS [60]. As a continuation of the research work on the protective effects of liver, Taner et al. analyzed the molecular signatures of renal biopsies after a renal transplantation alone as well as after a renal transplantation in combination with liver; the cohort consisted of 28 patients divided into the following four groups on the basis of their crossmatch (XM): (+XM SLKT, $\mathrm{XM}$ SLKT, +XM KT, and -XM KT). Despite the small number of patients included in the study, the author defended the hypothesis that liver contributes to the absorption of DSA through the endothelial surface, a phenomenon referred to as the "high dose effect". This protective effect of the liver is reflected through the differential expression of genes associated with inflammation and tissue repair. For instance, it has been observed that at one year, there was a lower expression of inflammatory, endothelial, and DSA-selective transcript set in the kidney allografts (+XM SLKT) compared to the +XM KT grafts [61]. The Kidney Donor Profile Index (KDPI) summarizes the probability of transplant failure after deceased-donor kidney transplantation. In KDPI, lower scores are associated with a longer estimated renal function, while higher scores are associated with a shorter duration of estimated renal function. The KDPI score for the kidneys transplanted in SLKT was $36 \%$, while that for the kidney alone transplants was $46 \%$, in a study with the objective of improving survival in early hepatic transplantation with renal insufficiency [62].

\subsection{Heart-Liver Transplant}

In regard to liver transplantation, Starzl is the pioneer in the field, with the first heart-liver combined transplant conducted on a six-year-old girl back in 1984. Despite the lack of comparative studies, the available data suggest that the incidence of rejection after a combined liver-heart transplant is lower than that after the liver transplantation alone. Cardiac rejection observed after combined liver-heart transplantation was $13 \%$, compared to the $60 \%$ rejected observed after isolated heart transplantation [63]. The survival of the graft after heart-liver combined graft (80\% at one year and greater than $70 \%$ at ten years) was similar to that observed in case of isolated heart and isolated liver grafts [64]. The indications of the combined heart-liver transplant were heterogeneous. In genetic diseases with cardiac damage as the main damage caused, such as amyloid neuropathy, classic cardiac transplantation indications were observed to be associated with hepatopathy, while classic indications of liver transplantation were observed to be associated with severe heart disease. In a large single-center series of studies, a lower-than-expected rejection rate in the combined liver-heart transplants could be attributed to the protective effect 
provided by the hepatic allograft to the cardiac allograft [65]. A retrospective study conducted by Taner [66] identified that despite similar IS, the incidence of T-cell-mediated rejection was lower in the liver-heart combined grafts (31.8\%) in comparison to that in the liver transplantation alone (84\%); however, no significant difference was observed in the antibody-mediated rejection (4.5\% versus $14.8 \% ; p=0.33$ ). While humoral rejection has become a rarity in cardiac transplants, it nevertheless represents a problem of clinical management owing to the diagnostic difficulty and low predictive evidence associated with it. It has been demonstrated that when hepatic transplantation precedes a cardiac transplant, there is a reduction in DSA and the positive crossmatch becomes negative again [67]. Moreover, a few authors have suggested a correlation between the protective effect of the liver and the decrease in the IS treatment.

\subsection{Lung-Liver Transplantation}

This type of intervention is performed only in the transplant centers, which have double expertise in thoracic and abdominal transplantation. Owing to its complexity, this procedure is rare and requires coordination between several teams. The "liver first" approach introduced in 2014 by Ceulemans et al. was aimed at reducing the cold ischemic time of the liver, in order to minimize the rate of biliary stenosis after the liver transplantation, while it prevented the other complications as well [68]. The 5-year survival of these patients was $80 \%$ compared to the $20 \%$ observed in the standard procedure [69]. A retrospective study conducted by $\mathrm{Yi}$ et al. demonstrated a decrease in the acute rejection episode, although it did not conclude the protective effect of the liver. However, it was interesting to note a reduction in the immunosuppression in the first year [70].

\subsection{Pancreatic-Liver Transplantation}

According to United Organ Network Sharing, a total of 28 patients received a combined pancreatic cystic fibrosis transplant between the years 1984 and 2014 . The study conducted by Mekeel on a small cohort of patients demonstrated that survival could reach $100 \%$ in five years in the liver-pancreas transplantation when compared to the $83 \%$ observed for the hepatic transplantation alone; all the patients with combined hepatic-pancreas transplantation were deprived of insulin and did not require supplementation with pancreatic enzymes [71]. It has been demonstrated in preclinical studies that hepatic graft plays a protective role and reverses the continuous rejection of the pancreatic graft, producing subsequent pancreatic tolerance [72]. Similarly, in a multicenter clinical study, it was speculated that pancreas-liver combined graft exhibited long-term superior pancreatic graft survival compared to the pancreas graft alone, although no confirmation regarding this speculation was established [73].

\subsection{Intestinal-Liver Transplantation}

Infections and surgical complications are a hindrance to the beneficial effects obtained in liver transplantation [74, 75]. Indeed, prolonged anhepatic phase and ischemia-reperfusion injury appear to be responsible for early death in the cases of combined liver and intestinal grafts. However, although the short-term survival appears to have improved, owing to IS treatment and advanced care, the fact remains that the 5-year survival does not exceed $60 \%$ in the isolated intestinal transplants [76]. A retrospective study conducted in a center compared children who 
had undergone a small bowel transplant (whether associated with liver transplantation or not) to 15 child controls in the time period between 1994 and 1998. First, it was suggested that the early events occurring during the ischemia-reperfusion phase could be participating in the protective effect of the liver on the intestinal grafts, and these events correspond to the significant differences observed in the NF-KB expression in the intestinal biopsies obtained at Day 0 immediately after reperfusion. Indeed, a decrease in the induction of NF-kB during the early phase of transplantation, therefore, plays a protective role against the allo-immune response [77]. Another more recent study highlighted the protective effect of liver on the severity of the acute episode of cell rejection, on the incidence of chronic rejection, as well as on the acute rejection induced by antibodies, while the infection was the leading cause of graft loss, suggesting that the reduction in IS may be considered for reducing the increased risk of infection [78].

\section{Conclusion}

Apart from the indispensable position of immunosuppression and the innovative aspects of certain therapeutic approaches (such as cell therapy) for obtaining tolerance, different studies have demonstrated that liver has a protective property for facilitating the engraftment of other organs. However, no cases of operational tolerance in combined liver transplantation have been reported so far. It is obvious that the correlation between the protective effect and the occurrence of tolerance is not proof of causality. The mechanisms involved in the induction of tolerance as well as its maintenance are closely intertwined and complex. For instance, the study conducted by Rana revealed that the combined grafts other than those of the liver are less prone to rejection, and the most probable mechanism underlying this would be the exposure of the antigenic charge in correlation with graft surface. In the long term (ten years), this mechanism could reduce or even wean the patient from immunosuppression. Is it possible to discuss operational tolerance? Further studies are required to be conducted with this category of patients who receive more than one graft. In this context, biomarkers would play a role in the detection of rejection, prediction of favorable outcomes in the recipients, and the identification of the pre-selected patients likely to be tolerant, in addition to allowing the decision of withdrawal of the immunosuppression. The problem associated with combined liver transplant is, essentially, the severity of the pathology for which the patient is grafted, the attribution and the shortage of organ, and also the preservation of the organs prior to the transplantation. However, recent studies have produced promising results in terms of organ function and patient survival.

\section{Author Contributions}

Both authors contributed equally to this work.

\section{Competing Interests}

The authors have declared that no competing interests exist.

\section{References}

1. Ojo AO, Held PJ, Port FK, Wolfe RA, Leichtman AB, Young EW, et al. Chronic renal failure after transplantation of a nonrenal organ. N Engl J Med. 2003; 349: 931-940. 
2. Gijtenbeek JM, van den Bent MJ, Vecht CJ. Cyclosporine neurotoxicity: A review. J Neurol. 1999; 246: 339-346.

3. Tjon AS, Sint Nicolaas J, Kwekkeboom J, de Man RA, Kazemier G, Tilanus HW, et al. Increased incidence of early de novo cancer in liver graft recipients treated with cyclosporine: An association with C2 monitoring and recipient age. Liver Transpl. 2010; 16: 837-846.

4. Bianchi G, Marchesini G, Marzocchi R, Pinna AD, Zoli M. Metabolic syndrome in liver transplantation: Relation to etiology and immunosuppression. Liver Transpl. 2008; 14: 1648-1654.

5. Levitsky J. Operational tolerance: Past lessons and future prospects. Liver Transpl. 2011; 17: 222-232.

6. Billingham RE, Brent L, Medawar PB. Acquired tolerance of skin homografts. Ann N Y Acad Sci. 1955; 59: 409-416.

7. Medawar PB, Woodruff MF. The induction of tolerance by skin homografts on newborn rats. Immunology. 1958; 1: 27-35.

8. Merrill JP, Murray JE, Harrison JH, Guild WR. Successful homotransplantation of the human kidney between identical twins. J Am Med Assoc. 1956; 160: 277-282.

9. Starzl TE, Demetris AJ, Trucco M, Murase N, Ricordi C, Ildstad S, et al. Cell migration and chimerism after whole-organ transplantation: The basis of graft acceptance. Hepatology. 1993; 17: 1127-1152.

10. Rana A, Robles S, Russo MJ, Halazun KJ, Woodland DC, Witkowski P, et al. The combined organ effect: Protection against rejection? Ann Surg. 2008; 248: 871-879.

11. Adams DH, Sanchez-Fueyo A, Samuel D. From immunosuppression to tolerance. J Hepatol. 2015; 62: S170-S185.

12. Welsh KI, Batchelor JR, Maynard A, Burgos H. Failure of long surviving, passively enhanced kidney allografts to provoke T-dependent alloimmunity. II. Retransplantation of (AS X AUG)F1 kidneys from AS primary recipients into (AS X WF)F1 secondary hosts. J Exp Med. 1979; 150: 465-470.

13. Ko S, Deiwick A, Jager MD, Dinkel A, Rohde F, Fischer R, et al. The functional relevance of passenger leukocytes and microchimerism for heart allograft acceptance in the rat. Nat Med. 1999; 5: 1292-1297.

14. Rokahr KL, Sharland AF, Sun J, Wang C, Sheil AG, Yan Y, et al. Paradoxical early immune activation during acceptance of liver allografts compared with rejection of skin grafts in a rat model of transplantation. Immunology. 1998; 95: 257-263.

15. Bishop GA, Wang C, Sharland AF, McCaughan G. Spontaneous acceptance of liver transplants in rodents: evidence that liver leucocytes induce recipient T-cell death by neglect. Immunol Cell Biol. 2002; 80: 93-100.

16. Goldberg LC, Bradley JA, Connolly J, Friend PJ, Oliveira DB, Parrott NR, et al. Anti-CD45 monoclonal antibody perfusion of human renal allografts prior to transplantation. A safety and immunohistological study. CD45 Study Group. Transplantation. 1995; 59: 1285-1293.

17. Starzl TE, Demetris AJ, Murase N, Ildstad S, Ricordi C, Trucco M. Cell migration, chimerism, and graft acceptance. Lancet. 1992; 339: 1579-1582.

18. Qian S, Demetris AJ, Murase N, Rao AS, Fung JJ, Starzl TE. Murine liver allograft transplantation: tolerance and donor cell chimerism. Hepatology. 1994; 19: 916-924.

19. Elwood ET, Larsen CP, Maurer DH, Routenberg KL, Neylan JF, Whelchel JD, et al. Microchimerism and rejection in clinical transplantation. Lancet. 1997; 349: 1358-1360. 
20. Bettens F, Tiercy JM, Campanile N, Giostra E, Majno P, Rubbia L, et al. Microchimerism after liver transplantation: Absence of rejection without abrogation of anti-donor cytotoxic Tlymphocyte-mediated alloreactivity. Liver Transpl. 2005; 11: 290-297.

21. Henao-Mejia J, Elinav E, Thaiss CA, Licona-Limon P, Flavell RA. Role of the intestinal microbiome in liver disease. J Autoimmun. 2013; 46: 66-73.

22. Ma HD, Wang YH, Chang C, Gershwin ME, Lian ZX. The intestinal microbiota and microenvironment in liver. Autoimmun Rev. 2015; 14: 183-191.

23. Bertolino $P$, Trescol-Biémont MC, Rabourdin-Combe $C$. Hepatocytes induce functional activation of naive CD8+ T lymphocytes but fail to promote survival. Eur J Immunol. 1998; 28: 221-236.

24. Wong YC, McCaughan GW, Bowen DG, Bertolino P. The CD8 T-cell response during tolerance induction in liver transplantation. Clin Transl Immunology. 2016; 5: e102.

25. Nakamoto $\mathrm{N}$, Kanai $\mathrm{T}$. Role of toll-like receptors in immune activation and tolerance in the liver. Front Immunol. 2014; 5: 221.

26. Hume DA, Allan W, Hogan PG, Doe WF. Immunohistochemical characterisation of macrophages in human liver and gastrointestinal tract: Expression of CD4, HLA-DR, OKM1, and the mature macrophage marker 25F9 in normal and diseased tissue. J Leukoc Biol. 1987; 42: 474-484.

27. Bartlett AS, McCall JL, Ameratunga R, Yeong ML, Gane E, Munn SR. Analysis of intragraft gene and protein expression of the costimulatory molecules, CD80, CD86 and CD154, in orthotopic liver transplant recipients. Am J Transplant. 2003; 3: 1363-1368.

28. Heymann F, Peusquens J, Ludwig-Portugall I, Kohlhepp M, Ergen C, Niemietz P, et al. Liver inflammation abrogates immunological tolerance induced by Kupffer cells. Hepatology. 2015; 62: 279-291.

29. Jenne CN, Kubes P. Immune surveillance by the liver. Nat Immunol. 2013; 14: 996-1006.

30. Doherty DG. Immunity, tolerance and autoimmunity in the liver: A comprehensive review. J Autoimmun. 2016; 66: 60-75.

31. Hsieh CC, Hung CH, Lu L, Qian S. Hepatic immune tolerance induced by hepatic stellate cells. World J Gastroenterol. 2015; 21: 11887-11892.

32. Morita M, Joyce D, Miller C, Fung JJ, Lu L, Qian S. Rejection triggers liver transplant tolerance: Involvement of mesenchyme-mediated immune control mechanisms in mice. Hepatology. 2015; 62: 915-931.

33. Okumi M, Fishbein JM, Griesemer AD, Gianello PR, Hirakata A, Nobori S, et al. Role of persistence of antigen and indirect recognition in the maintenance of tolerance to renal allografts. Transplantation. 2008; 85: 270-280.

34. Demirkiran A, Bosma BM, Kok A, Baan CC, Metselaar HJ, ljzermans JN, et al. Allosuppressive donor $\mathrm{CD} 4+\mathrm{CD} 25+$ regulatory $\mathrm{T}$ cells detach from the graft and circulate in recipients after liver transplantation. J Immunol. 2007; 178: 6066-6072.

35. Li W, Carper K, Liang Y, Zheng XX, Kuhr CS, Reyes JD, et al. Anti-CD25 mAb administration prevents spontaneous liver transplant tolerance. Transplant Proc. 2006; 38: 3207-3208.

36. Joffre O, Santolaria T, Calise D, Al Saati T, Hudrisier D, Romagnoli P, et al. Prevention of acute and chronic allograft rejection with $\mathrm{CD} 4+\mathrm{CD} 25+$ Foxp3+ regulatory $\mathrm{T}$ lymphocytes. Nat Med. 2008; 14: 88-92. 
37. Safinia N, Scotta C, Vaikunthanathan T, Lechler RI, Lombardi G. Regulatory T cells: Serious contenders in the promise for immunological tolerance in transplantation. Front Immunol. 2015; 6: 438.

38. Bohne F, Londono MC, Benitez C, Miquel R, Martinez-Llordella M, Russo C, et al. HCV-induced immune responses influence the development of operational tolerance after liver transplantation in humans. Sci Transl Med. 2014; 6: 242ra281.

39. Bohne F, Martínez-Llordella M, Lozano JJ, Miquel R, Benítez C, Londoño MC, et al. Intra-graft expression of genes involved in iron homeostasis predicts the development of operational tolerance in human liver transplantation. J Clin Invest. 2012; 122: 368-382.

40. Creput C, Durrbach A, Samuel D, Eschwege P, Amor M, Kriaa F, et al. Incidence of renal and liver rejection and patient survival rate following combined liver and kidney transplantation. Am J Transplant. 2003; 3: 348-356.

41. Creput C, Le Friec G, Bahri R, Amiot L, Charpentier B, Carosella E, et al. Detection of HLA-G in serum and graft biopsy associated with fewer acute rejections following combined liver-kidney transplantation: Possible implications for monitoring patients. Hum Immunol. 2003; 64: 1033-1038.

42. Castellaneta A, Mazariegos GV, Nayyar N, Zeevi A, Thomson AW. HLA-G level on monocytoid dendritic cells correlates with regulatory T-cell Foxp3 expression in liver transplant tolerance. Transplantation. 2011; 91: 1132-1140.

43. Benítez C, Londoño MC, Miquel R, Manzia TM, Abraldes JG, Lozano JJ, et al. Prospective multicenter clinical trial of immunosuppressive drug withdrawal in stable adult liver transplant recipients. Hepatology. 2013; 58: 1824-1835.

44. Li Y, Koshiba T, Yoshizawa A, Yonekawa Y, Masuda K, Ito A, et al. Analyses of peripheral blood mononuclear cells in operational tolerance after pediatric living donor liver transplantation. Am J Transplant. 2004; 4: 2118-2125.

45. Yu X, Liu Z, Wang $Y$, Wang $H$, Zhang $M$, Sun $Y$, et al. Characteristics of V $\delta 1(+)$ and V $\delta 2(+) ~ \gamma \delta T$ cell subsets in acute liver allograft rejection. Transpl Immunol. 2013; 29: 118-122.

46. Shi XL, de Mare-Bredemeijer EL, Tapirdamaz Ö, Hansen BE, van Gent R, van Campenhout MJ, et al. CMV primary infection is associated with donor-specific $T$ cell hyporesponsiveness and fewer late acute rejections after liver transplantation. Am J Transplant. 2015; 15: 2431-2442.

47. Mazariegos GV, Zahorchak AF, Reyes J, Ostrowski L, Flynn B, Zeevi A, et al. Dendritic cell subset ratio in peripheral blood correlates with successful withdrawal of immunosuppression in liver transplant patients. Am J Transplant. 2003; 3: 689-696.

48. Millán O, Benitez C, Guillén D, López A, Rimola A, Sánchez-Fueyo A, et al. Biomarkers of immunoregulatory status in stable liver transplant recipients undergoing weaning of immunosuppressive therapy. Clin Immunol. 2010; 137: 337-346.

49. Singh N, Djamali A, Lorentzen D, Pirsch JD, Leverson G, Neidlinger N, et al. Pretransplant donor-specific antibodies detected by single-antigen bead flow cytometry are associated with inferior kidney transplant outcomes. Transplantation. 2010; 90: 1079-1084.

50. Mizutani K, Terasaki P, Hamdani E, Esquenazi V, Rosen A, Miller J, et al. The importance of anti-HLA-specific antibody strength in monitoring kidney transplant patients. Am J Transplant. 2007; 7: 1027-1031.

51. O'Leary JG, Kaneku H, Susskind BM, Jennings LW, Neri MA, Davis GL, et al. High mean fluorescence intensity donor-specific anti-HLA antibodies associated with chronic rejection Postliver transplant. Am J Transplant. 2011; 11: 1868-1876. 
52. Kaneku H, O'Leary JG, Taniguchi M, Susskind BM, Terasaki PI, Klintmalm GB. Donor-specific human leukocyte antigen antibodies of the immunoglobulin $\mathrm{G} 3$ subclass are associated with chronic rejection and graft loss after liver transplantation. Liver Transpl. 2012; 18: 984-992.

53. Locke JE, Warren DS, Singer AL, Segev DL, Simpkins CE, Maley WR, et al. Declining outcomes in simultaneous liver-kidney transplantation in the MELD era: Ineffective usage of renal allografts. Transplantation. 2008; 85: 935-942.

54. Nilles KM, Krupp J, Lapin B, Sustento-Reodica N, Gallon L, Levitsky J. Incidence and impact of rejection following simultaneous liver-kidney transplantation. J Hepatol. 2015; 62: 340-345.

55. Issa N, Kukla A, Ibrahim HN. Calcineurin inhibitor nephrotoxicity: A review and perspective of the evidence. Am J Nephrol. 2013; 37: 602-612.

56. Perumpail RB, Wong RJ, Scandling JD, Ha le D, Todo T, Bonham CA, et al. HCV infection is associated with lower survival in simultaneous liver kidney transplant recipients in the United States. Clin Transplant. 2015; 29: 920-926.

57. Wang CS, Ko HH, Yoshida EM, Marra CA, Richardson K. Interferon-based combination antiviral therapy for hepatitis $C$ virus after liver transplantation: A review and quantitative analysis. Am J Transplant. 2006; 6: 1586-1599.

58. Taner T, Heimbach JK, Rosen CB, Nyberg SL, Park WD, Stegall MD. Decreased chronic cellular and antibody-mediated injury in the kidney following simultaneous liver-kidney transplantation. Kidney Int. 2016; 89: 909-917.

59. Taner T, Gustafson MP, Hansen MJ, Park WD, Bornschlegl S, Dietz AB, et al. Donor-specific hypo-responsiveness occurs in simultaneous liver-kidney transplant recipients after the first year. Kidney Int. 2018; 93: 1465-1474.

60. Dumontet E, Danger R, Vagefi PA, Londono MC, Pallier A, Lozano JJ, et al. Peripheral phenotype and gene expression profiles of combined liver-kidney transplant patients. Liver Int. 2016; 36: 401-409.

61. Taner T, Park WD, Stegall MD. Unique molecular changes in kidney allografts after simultaneous liver-kidney compared with solitary kidney transplantation. Kidney Int. 2017; 91: 1193-1202.

62. Miles CD, Westphal S, Liapakis A, Formica R. Simultaneous liver-kidney transplantation: Impact on liver transplant patients and the kidney transplant waiting list. Curr Transplant Rep. 2018; 5: 1-6.

63. Raichlin E, Daly RC, Rosen CB, McGregor CG, Charlton MR, Frantz RP, et al. Combined heart and liver transplantation: A single-center experience. Transplantation. 2009; 88: 219-225.

64. Cannon RM, Hughes MG, Jones CM, Eng M, Marvin MR. A review of the United States experience with combined heart-liver transplantation. Transpl Int. 2012; 25: 1223-1228.

65. Atluri P, Gaffey A, Howard J, Phillips E, Goldstone AB, Hornsby N, et al. Combined heart and liver transplantation can be safely performed with excellent short- and long-term results. Ann Thorac Surg. 2014; 98: 858-862.

66. Wong TW, Gandhi MJ, Daly RC, Kushwaha SS, Pereira NL, Rosen CB, et al. Liver allograft provides immunoprotection for the cardiac allograft in combined heart-liver transplantation. Am J Transplant. 2016; 16: 3522-3531.

67. Daly RC, Topilsky Y, Joyce L, Hasin T, Gandhi M, Rosen C, et al. Combined heart and liver transplantation: Protection of the cardiac graft from antibody rejection by initial liver implantation. Transplantation. 2013; 95: e2-e4. 
68. Ceulemans L, Monbaliu D, Verslype C, van der Merwe S, Laleman W, Vos R, et al. Combined liver and lung transplantation with extended normothermic lung preservation in a patient with end-stage emphysema complicated by drug-induced acute liver failure. Am J Transplant. 2014; 14: 2412-2416.

69. Salman J, Grannas G, lus F, Sommer W, Siemeni T, Avsar M, et al. The liver-first approach for combined lung and liver transplantation. Eur J Cardiothorac Surg. 2018; 54: 1122-1127.

70. Yi SG, Burroughs SG, Loebe M, Scheinin S, Seethamraju H, Jyothula S, et al. Combined lung and liver transplantation: Analysis of a single-center experience. Liver Transpl. 2014; 20: 46-53.

71. Mekeel KL, Langham MR, Jr., Gonzalez-Perralta R, Reed A, Hemming AW. Combined en bloc liver pancreas transplantation for children with CF. Liver Transpl. 2007; 13: 406-409.

72. Wang C, Sun J, Li L, Wang L, Dolan P, Sheil AG. Conversion of pancreas allograft rejection to acceptance by liver transplantation. Transplantation. 1998; 65: 188-192.

73. Bandsma RH, Bozic MA, Fridell JA, Crull MH, Molleston J, Avitzur Y, et al. Simultaneous liverpancreas transplantation for cystic fibrosis-related liver disease: A multicenter experience. J Cyst Fibros. 2014; 13: 471-477.

74. Gupte GL, Haghighi KS, Sharif K, Mayer DA, Beath SV, Kelly DA, et al. Surgical complications after intestinal transplantation in infants and children--UK experience. J Pediatr Surg. 2010; 45: 1473-1478.

75. Dopazo C, Gupte GL, Sharif K, Perera MT, Hartley J, Muiesan P, et al. Combined liver-intestine grafts compared with isolated intestinal transplantation in children: $A$ single-center experience. Transplantation. 2012; 94: 859-865.

76. Grant D, Abu-Elmagd K, Mazariegos G, Vianna R, Langnas A, Mangus R, et al. Intestinal transplant registry report: Global activity and trends. Am J Transplant. 2015; 15: 210-219.

77. Jugie M, Canioni D, Le Bihan C, Sarnacki S, Revillon Y, Jan D, et al. Study of the impact of liver transplantation on the outcome of intestinal grafts in children. Transplantation. 2006; 81: 992-997.

78. Wu G, Cruz RJ, Jr. Liver-inclusive intestinal transplantation results in decreased alloimmunemediated rejection but increased infection. Gastroenterol Rep. 2018; 6: 29-37.

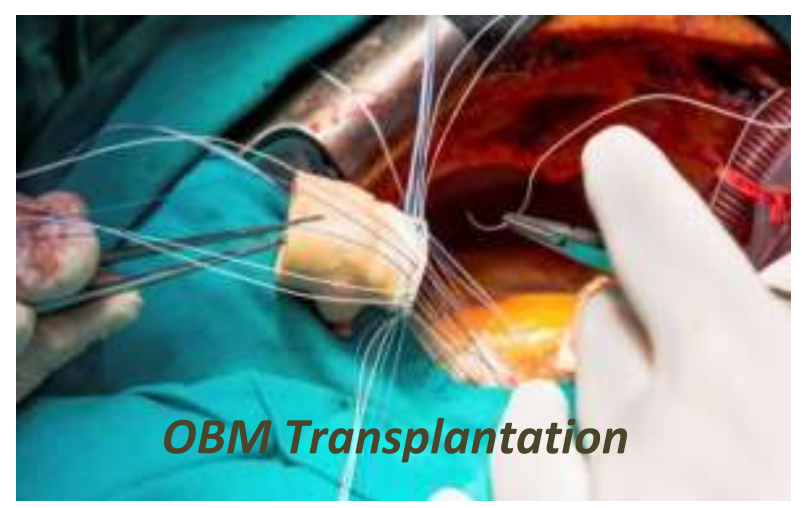

Enjoy OBM Transplantation by:

1. Submitting a manuscript

2. Joining in volunteer reviewer bank

3. Joining Editorial Board

4. Guest editing a special issue

For more details, please visit:

http://www.lidsen.com/journals/transplantation 